\title{
Early Transition Trends and Differences of Higher Education Attainment in the Former Soviet Union, Central and Eastern European Countries
}

EMMA TERAMA, Institute for Sustainable Resources, University College London (UCL), UK

ANU KÕU, Population Research Centre, University of Groningen, the Netherlands

SAMIR KC, World Population Program, International Institute for Applied Systems Analysis (IIASA), Laxenburg, Austria

\section{Abstract}

The past trends in tertiary education attainment of selected post-communist countries are investigated through population projections. Did a common higher education policy manifest itself through attainment levels, and how did the situation change after the collapse of the Soviet regime? The approach is based on comprehensive backprojections ranging from year 2000 to 1970. Descriptive findings for most countries show that the level of tertiary education attainment for women has surpassed that of men sooner than in Western Europe. Results are discussed in light of individual countries' pre-war higher education models and former communist policy, and possible implications are derived for future study of higher education attainment.

Keywords: higher education; FSU; CEE; population projections; equality; tertiary attainment

\section{Introduction}

The period from 1989 to 1991 will remain in history due to the fall of the statesocialist regimes in Europe and affiliated countries on the border of Europe. Most of these countries entered a process towards democratization and liberalization of their governance structures and financial markets that proved to be a long transition rather than a quickly accomplished leap. The same applies to the higher education system.

Each national higher education system can be defined as the historically, politically and culturally contingent institution that organises science and learning (David-Fox and Péteri 2000). During the socialist era, these nationally specific institutions were 
brought under common policy and thus largely harmonised in terms of governance, admissions and curriculum. Despite the remaining national variation that will become clear also in this paper, what is common to these education systems is of paramount importance, namely the 'Soviet-type' academic regime that governed the institutions from different starting points up to 1989-1991, the onset of the transition. As a result of this regime, may it be without a particular 'master plan' (David-Fox and Péteri 2000:27), the countries participating in it ended up with higher education systems largely resembling one another.

These systems have been observed and analysed before from the point of view of sociology and/or gender (Saar et al. 2008, Smyth and Steinmetz 2008, Charles 2005, Pascall and Lewis 2004 and Charles and Bradley 2002) and education policy (Dobbins 2011, Heyneman 2008, Silova 2005 and Tomusk 2004), in country and region specific studies (Heynemann 2007, Jolliffe and Campos 2005, Tominc 2001, Lobodzinska 2000, Paternostro and Sahn 1999 and Stanovnik 1997) and in studies pertaining to the transformation and reform processes (Brunner and Tillet 2007, Silova 2004, Paci 2002, Newell and Reilly 1999 and Hüfner 1995). In contrast to earlier work, this study has taken a demographic and comparative point of view, ranging from methodology to analysis, observing the changes of higher education attainment by country, cohort and gender, correcting for partial or incomparable data. It is the first study of its kind to use a comprehensive dataset to compare a vast number of countries linked through a political history, and then attempt to connect the findings to the national socioeconomic as well as political context of that time.

\section{Objectives}

It is the aim of this article to investigate and compare the effects of the unified education policy during the 1970s and 1980s on the national education outcomes and gender ratios of 19 countries. These are studied in terms of the higher education attainment levels and trajectories of men and women, which is expected to provide a missing quantitative link between known policies and qualitative discussions about higher education attainment and equality. The period of investigation extends until the first post-transition decade, namely the 1990s.

This study comprises the former Soviet republics Armenia, Estonia, Kazakhstan, Kyrgyzstan, Latvia, Lithuania, Russia, Turkmenistan, Ukraine and Uzbekistan, as well as the formerly communist states Bulgaria, Croatia, Czech Republic, Hungary, FYR of Macedonia, Poland, Romania, Slovakia and Slovenia. The following section gives some more background into the education systems under the Soviet regime, leading to Results of this study, followed by the Discussion, highlighting a selection of countries and findings that can be linked to the local policy environment and other work in this area. 


\section{Soviet 'knowledge economies'}

On the level of national education policy, a key issue of any education system to address is the provision of human capital needed for the level and diversity of skills required by the labour market, and the development of the national economy and society. High levels of human capital, especially for the young cohorts, are seen as drivers for development of knowledge economies and technology absorption (Crespo Cuaresma and Lutz 2007). During the Soviet era, however, this link was interpreted to mean educating the population according to the party needs for workers in industry and farming, thus securing high proportions of secondary education attainment and vocational training, and largely restricting access to higher (tertiary) education. This was done in some countries at the expense of existing higher education institutions, particularly in the departments of humanities and social sciences. Further, despite the massive public investments and subsequent growth of the Soviet higher education systems (Johnson 2008), it was far from achieving the quality and standards required to meet the assumption of providing for the national economic as well as technological development and 'superiority over the capitalist Western world' (Tomusk 2004:54).

Table 1. Pre-war higher education coordination by predominant model.

\begin{tabular}{|l|l|l|l|}
\hline $\begin{array}{l}\text { University gover- } \\
\text { nance model }\end{array}$ & $\begin{array}{l}\text { Referential } \\
\text { community }\end{array}$ & Role of state & $\begin{array}{l}\text { Prevalent model } \\
\text { until 1945 }\end{array}$ \\
\hline Humboldtian & $\begin{array}{l}\text { Scientific \& research } \\
\text { community }\end{array}$ & $\begin{array}{l}\text { Financer; promoter } \\
\text { of free scientific } \\
\text { inquiry }\end{array}$ & $\begin{array}{l}\text { Czechoslovakia, } \\
\text { Estonia, Hungary, } \\
\text { Poland }\end{array}$ \\
\hline Napoleonic & Nation-state & $\begin{array}{l}\text { System design for } \\
\text { national cohesion } \\
\text { and homogeneity }\end{array}$ & Russia, Romania \\
\hline Anglo-American & Local community & $\begin{array}{l}\text { Fostering competi- } \\
\text { tion and quality }\end{array}$ & Bulgaria \\
\hline
\end{tabular}

Source: Adapted from Dobbins 2011

Table 1 distinguishes between three different traditions of higher education coordination present in pre-war Europe and gives examples of Central and Eastern European (CEE) countries in which these were applied along the lines of Dobbins (2011). With the abolition of the Soviet regime starting from 1989, came the (further) downturn of higher education due to lack of education policy and/or insight as well as lack of the previously secure government funding. This brought the situation of the individual countries back to the pre-Soviet era (see Table 1) in which they had governed their education systems themselves, to a varying degree of success, thus providing for slightly different starting points at the onset of the transition. We hypothesise that depending 
on the pre-war education model, countries were in different positions to redeem their education policy principles after the Soviet break-up. This difference could in part explain the large variance in attainment levels in the transition period despite having had similar education trends during the Soviet era.

\section{Education System in the Soviet Era}

In order to comprehend the fundamental differences between the Western market economies and the Soviet societies with a single political party monopolizing decision making, basic functioning mechanisms of the once communist-led countries must be considered. Titma and Saar (1995) distinguish three such prevalent features. Firstly, there was the common disregard of an individual as a subject on its own. Instead, society as a whole was a central unit in the Soviet Union, which all the members had to serve for a collective goal. Another component was the identification of the Soviet state with the society as a whole, with the purpose to exercise power over various domains of social life and direct the civil society. A third element was the distribution of power to the ministries of specific fields; this domination of party-state institutions was the very reason why Soviet societies were totalitarian.

In line with the first feature, the authorities considered education a collective good. Therefore education was not a private matter, but to be used for the benefit of the society. By means of central planning and the rejection of private ownership, the apparatus aimed at creating ideal conditions for complete social equality (Kotasek 1993). Since opting for equality, issues such as gender differences, also in education, were denied. As Silova and Magno (2004) observe, gender issues were considered irrelevant due to, for example, relatively equal labour force participation and small gender pay gaps. Thus the 'women question' was 'solved on the basis of econometrics rather than social, cultural, and political measures' (Silova and Magno 2004: 418).

Education was exploited as a powerful tool for achieving overarching totality or uniformity, starting at the lower education levels. School structures, curricula, textbooks and teaching methods were standardised throughout, and teachers were given the responsibility to bring up the youth in the spirit of Marxist-Leninist ideology (Szebenyi 1992). New, Soviet-related subjects such as history, constitution and geography of the USSR received emphasis in the curricula. Russian language lessons were incorporated as well, largely at the cost of other foreign languages. The emphasis was strongly focused on factual knowledge; neither comprehension of the study material nor synthesis of analysis was encouraged in order to restrain students from critical thought.

Due to labour force deficit, that of low-skilled manual workers in particular, vocational training was introduced in the curricula, which gained even more prominence when vocational school at secondary education level was introduced (Titma et al. 2003). 
The compulsory eight-year school at the incomplete secondary education level was to be continued in three different tracks, a system that eventually led to enormous differences in terms of tertiary education and life chances (Gerber and Hout 1995, Titma and Saar 1995, Titma et al. 2010). Only the best students were allowed into (femaledominated) general secondary schools, which were more or less the only channels to universities. The second type of schools, so-called specialised secondary schools, gave students semi-professions such as teachers, nurses, or engineers. Thirdly, an increasing focus was placed on (male-dominated) vocational schools supplying the industrial and agricultural sectors. Students coming from vocational schools had very poor chances of proceeding to a higher education institution. Thus, by means of locking people into particular type of education, the Soviet state could easily plan the labour market outcomes (Titma et al. 2010). On the one hand, the education system of the Soviet Union provided almost universal access to primary and lower secondary education, but tertiary education, on the other hand, was subject to highly selective procedures (Micklewright 1999). The regime established wage grids where the income differences between skilled and unskilled jobs were relatively minimal in order to promote vocational education (Munich et al. 2005) and the overall aim of social equality.

The higher education system was significantly redesigned in the communist era. Research and teaching were commonly divided into different institutions, resulting in research being conducted at separate state research institutes. Much alike the lower tiers of education, courses in dialectical materialism and the history of the Communist Party were incorporated in every study programme, as well as Russian language. Engineering and science specialities were allocated disproportionately large quotas by central authorities, planned for swift economic returns and increase in the defence sector, rather than stemming from the actual labour market dynamics (Gerber and Schaefer 2004). The apparatus strived for control over the composition of students in tertiary education, doing so by means of promoting students from working class or peasant families as well as enforcing other forms of social control (Ganzeboom and Nieuwbeerta 1999, Simkus and Andorka 1982). Quotas were set for the admission of students of proletarian background, whereas students from the 'wrong' families (intelligentsia, bourgeois, political affiliation other than communist) were impeded from entry to tertiary education by merits or deportations to rural areas. Additionally, when applying for a university, students were required to present a recommendation letter from a Party member or a trade unionist. Direct admission was ensured for people already in a leading position in the Party as well as students who had some years of work experience. Ever since the 1960s, admission to higher education institutions was thus limited, partly in order to channel the high school graduates to less popular jobs in the reconstruction and agricultural sectors. Despite the regime's aims to reduce social reproduction and increase social equality, parents' educational attainment continued to be one of the main contributors to disparity in educational opportunities throughout 
the Soviet period as well as during the transition period, the effect remaining stronger than in Western countries (Ganzeboom and Nieuwbeerta 1999, Gerber and Hout 1995, Mateju et al. 2004, Saar 1997).

\section{Method}

In addition to a literature review on policy and practice, this research is based on demographic multi-state population projections that allow vital rates in different educational categories to differ. Multi-state projections are today a well-accepted method among technical demographers. The use of the current projections is a means to obtain a comprehensive dataset across several decades that can be applied to questions pertaining to subjects of little documentation or reliable data across the chosen time period.

The concept of back-projections has been known since the early 1980s. Examples include the projections by Wrigley and Schofield (1982), inverse projections carried out by Lee (1985) and more recent studies by Barro and Lee $(2000,2010)$. The method has been applied to e.g. estimations of HIV and heroin use incidences based on later availability of AIDS statistics, and opiate-related deaths and methadone treatment (Law et al. 2001). Back-projections are a powerful tool to overcome problems such as scattered, unreliable sources or even non-existing data, as long as sufficient data is available at the starting point of the projection period.

In this study, the baseline providing the empirical starting point is the year 2000. This was chosen as the base year since the data for 2005 were not available for all countries. The population is distributed by five-year age groups, from the age of 15 to $100+$ by sex, and by four levels of educational attainment. With reference to the ISCED classification of education levels by UNESCO (1997) they are: no education, primary (ISCED 1), secondary (ISCED 2-4) and tertiary education (ISCED 5-6).

Starting with an empirical dataset for each country for the year 2000, the population proportions with different educational attainment for each five-year age group of men and women was reconstructed back to 1970 . This means going back in time and reconfiguring earlier distributions by level of education along cohort lines. The overall size and age distribution of the population for each country and time point is given by the United Nations (UN) Population Division. It is assumed that the educational attainment of a person remains invariant after a certain age, e.g. the proportion of women without any formal education aged 50-54 in 1995 can be derived directly from the proportion of women without any formal education aged 55-59 in 2000. Continuing to assume that this proportion is constant along cohort lines, the proportion of women without education aged 25-29 in 1970 for the same cohort follows directly. Equation (1) demonstrates the principle: 
Nage-5,edu,t-5,sex $=[$ Nage,edu,t,sex ] / SurvivalRatioage-5,edu,t-5,sex]

where $N$ is the size of the population with characteristics in terms of age, education and gender at a given time, and SurvivalRatio is the proportion of people with the same characteristics surviving for the five following years. In a similar manner, the proportions for each educational category and each age group of men and women can simply be moved to the previous five-year age group as one moves back in time in five-year steps. Unlike previous models, the current model developed by Samir K.C.and co-workers takes into account the education specific mortality and migration rates and introduces adjustments for these differentials. A more detailed description of the model has been documented earlier, see Lutz et al. (2007).

Population projections inherently contain uncertainty, and should thus always be interpreted with caution. All projections, including back-projections, are possible scenarios and should be treated as such. However, it can be noted that demographic changes are sluggish in being transferred to educational attainment. This means that it takes many decades for a dramatic change in the educational level of young cohorts to significantly affect the educational level of the whole population. Population backprojections can thus be relevant in many ways, and indicate trends very close to the actual past depending on e.g. migration events.

\section{Results}

Figures 1 and 2 show the trend in higher education attainment for all 19 countries across the period of study. In Figure 1 is depicted the situation for the whole working age population, here 25-64 year olds, aggregated for the 19 countries. At the onset of the study period, men have higher proportions of tertiary attainment than women. Then women start catching up and surpass men in absolute numbers (Fig. 1) as well as in the share of higher educated, and proportion of cohort educated (figures not shown). In Figure 2 each country is represented by a marker, and the axes give the proportion of tertiary educated in the 30-34-year-old cohort by gender. This particular cohort is chosen because it is the group to have most likely just completed their higher education without diluting possible new generation effects across the whole working age population. The diagonal represents the 50/50 division, or equal share of both men and women attainers. For this cohort, women's attainment levels surpass men's earlier than for the whole working age population. Western Europe lags about ten years behind in this development (see e.g. OECD 2008).

Based on Figures 1 and 2, gender seems to play a key role in the past development of tertiary education attainment levels. Nearly all countries in this study have an increasing percentage of female tertiary attainment levels from 1980 to 2000, whereas the same is not true for the male counterparts. The finding is not explained by a previously 
higher level of male tertiary attainment, or in other words that women would have more catching up to do, since even in the beginning of the study period there was no great male advantage in tertiary attainment levels for these countries.

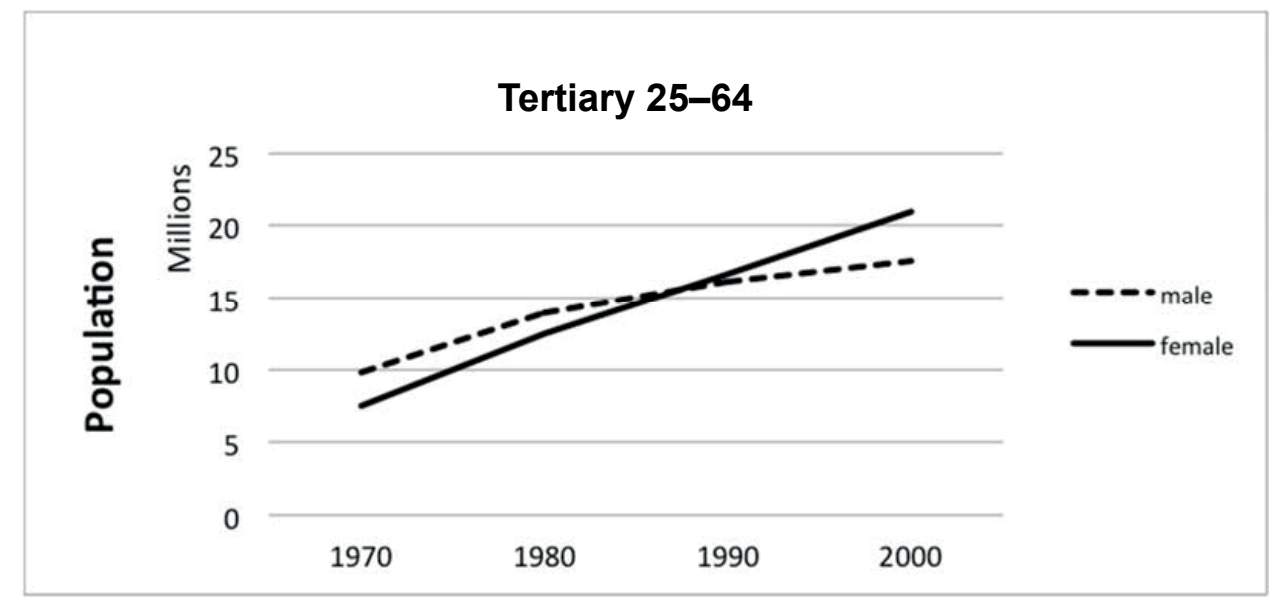

Figure 1. The trend in tertiary attainment levels of working age population for 19 Former Soviet Union (FSU) and CEE countries.
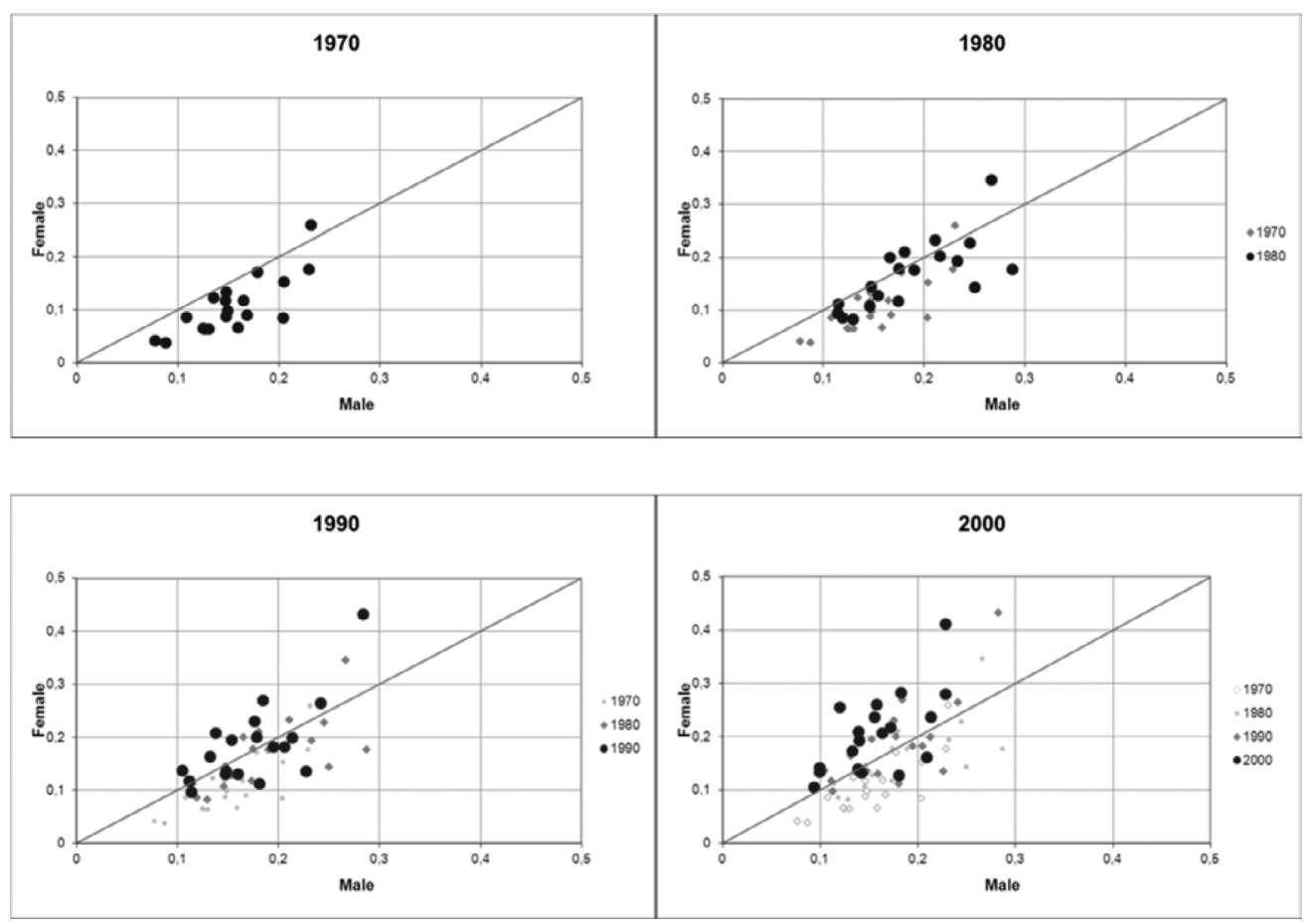

Figure 2. Tertiary education attainment levels (per cent of cohort) from 1970 to 2000 for $30-34$-year olds for 19 countries. 
Tertiary $30-34$

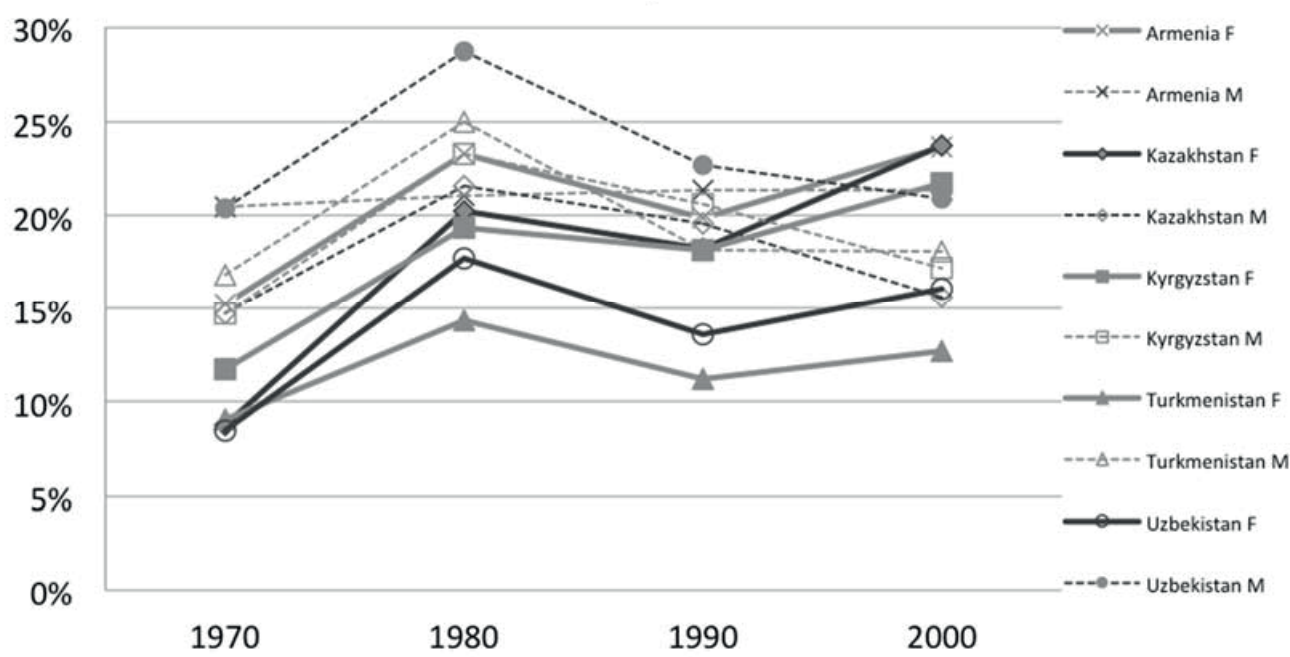

Figure 3. Tertiary attainment trends for the 30-34-year male (M) and female (F) cohort in the Asian FSU countries differ from the rest.

1970-2000

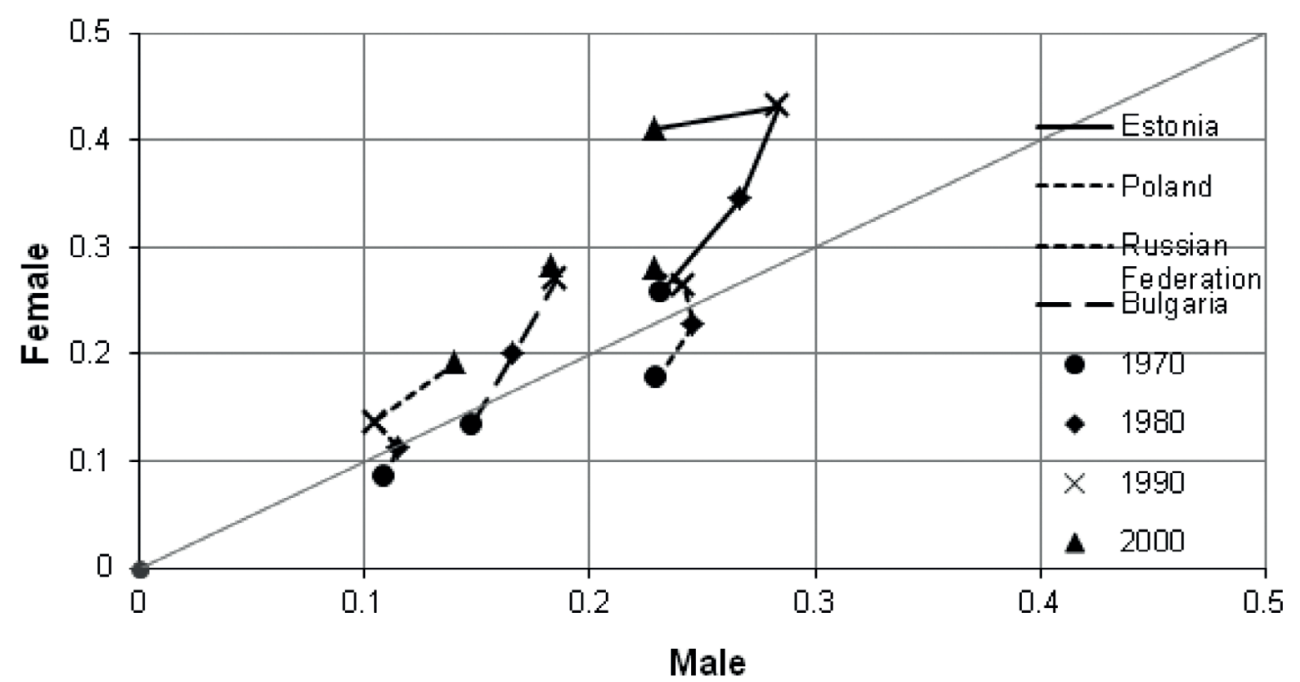

Figure 4. Country profiles of tertiary attainment levels for 30-34-year olds in Estonia, Poland, Russian Federation and Bulgaria. 
Figures 3 and 4 concentrate on highlights from selected countries. Figure 3 shows the exception to the above described pattern, since for these five Asian countries only, the female share of the educated cohort in fact declined over the study period (between 1980 and 1990). Figure 4 gives the gender-plot diagrams for four selected countries that show rather different educational pathways across the study period.

Estonia reaches the highest shares of graduates by cohort, while Russia shows the typical pattern of decreasing male tertiary attainment at the end of the period, while female attainment has just reached the same levels as the male attainment. Poland exhibits a pattern of increase in female attainment levels at the onset, and then an overall moderate increase in attainment levels, while Bulgaria exhibits a great and continuing increase of female graduates with only moderate increases for the male counterparts.

\section{Discussion}

The post-Soviet, transition era problems of higher education systems in FSU and CEE countries are similar, encompassing low salaries, lack of investment, faculty as well as students engaging in multiple employment, administrative rigidity, etc. (Tomusk 2004). At the same time the systems are quickly diversifying, according to their own needs and visions (cf. Table 1). The attainment numbers shown here being the results of (back) projections, it is reasonable to assume they depict the low end of numbers enrolled some five years prior to the given date. However, as the numbers of dropouts are difficult to estimate (hence low end of numbers enrolled), it is more reliable to use the attainment figures. A degree attainment period between 1990 and 2000 would translate into an active study and enrolment period between 1985 and 1995 thus covering the most turbulent years of the higher education systems in many postSoviet countries. Looking at the past 30-year trend in higher education attainment for all of the 19 countries, it is suggested that the Soviet model enhanced gender equality in higher education faster than in the Western European countries, given national differences in institutional infrastructure and secondary education levels feeding into higher education.

A special case in the group of 19 countries is Estonia, based on its high levels of tertiary education attainment for the 30-34 year olds, and the role of women especially. After the dissolution of the Soviet Union, Estonia continued promoting research just as in the pre-war era on the one hand, and on the other hand pursued the market-oriented education system of the Western countries. The shifted higher education gender balance in Estonia has happened much faster than in any other country, and is interesting in light of the unifying Soviet education policy.

Only the Asian FSU countries stand out as not having followed the general higher education trend of the rest of the FSU and CEE countries, namely that of clearly increasing female tertiary attainment accompanied by a moderate increase, decrease or 
stagnating male attainment. Uzbekistan had in fact in 1980 the highest male tertiary attainment level of all the countries studied at just below 30 per cent of the male 30-34-year-old cohort. After that the levels decreased substantially, with only Kazak and Armenian women of the Asian FSU achieving nearly 25 per cent tertiary attainment levels in year 2000 .

A bulk of literature attests to the slow advancement of women's status in many of the countries studied, despite the image of the Soviet approach as being gender neutral (Silova and Magno 2004, Łobodzinska 2000, Kostera et al. 1994). Combined with the diverging trends of the education attainment levels this may be a consequence of an alleged 'self-sovietisation' of the higher education system in many countries (DavidFox and Péteri 2000:164).

\section{FSU in Central Asia}

Why has this group of countries not followed the more general attainment trends? Historically, these countries share a different values and religious background. Most of these countries also suffered before and after the breakdown of the Soviet rule from elevated levels of corruption (for situation in 2001-2011 see e.g. Transparency International $\left.{ }^{1}\right)$. Heyneman $(2007,2008)$ has produced a body of research around the issue of corruption in higher education, conducting surveys and analysis on perceived as well as actual incidences of corruption in various European and Central Asian countries, and finds that the levels of corruption have increased after the breakdown of the Soviet regime. He further concludes that a nation's perceived corruption significantly reduces the payoff to higher education (Heyneman 2008) thus possibly explaining the decreasing levels of male graduates in these countries (cf. Fig. 3). Another possibility is that the formerly predominant focus on heavy industry shaped the higher education to meet its needs by educating more men through vocational channels thus explaining their lesser presence in higher education. However, the levels of corruption and its negative effect on the education institutions since 1990 does not seem to hamper women's advancement, in accordance with the general European trend of increasing female tertiary attainment levels. Neither has the absence of Soviet state control on industry and vocational training brought men back to higher education after 1990s.

\section{Estonia}

In the Soviet era, the higher education system was uniform according to the socialist standards dictated from Moscow, with no independence in areas such as planning, budgeting or curriculum development. Approximately 20 per cent of a cohort were accommodated in the system taking up studies related to science, engineering, agriculture and teacher training (Tomusk 2004). Tomusk (2004) identifies a first period

${ }^{1}$ http://www.transparency.org/policy_research/surveys_indices/cpi/2005, last accessed November 21, 2012 
of reforms during 1988-1992. This was the beginning of the diversification of the Estonian higher education system, perhaps earlier than in most of the Soviet countries. The private universities started emerging immediately, and thus by the early 1990s formed a whole new higher education subsector. In some ways, many legal reforms of the 1990s for the education sector have not been translated into active governance nor education policies (Tomusk 2004:35). At the same time, the reforms allow for needed distance between public universities and the state, without pressure to privatise the entire higher education sector, as seems to be the case in e.g. Kazakhstan. Estonia is therefore in a better position than many of its former Soviet counterparts.

Since 1989 the number of students in higher education has grown remarkably, nearly tripling by the early 2000. Between 1994/1995 and 2005/2006, enrolment in tertiary education increased by $168 \%$, constituting the highest growth rate among the OECD countries (OECD 2006) despite the fact that state-commissioned and merit-based places are allocated only to a certain number of students whereas the rest have to pay the tuition fees (OECD 2007). It has been criticised that the reported numbers of new entrants may exceed the number of high school graduates (Tomusk 2004). A reason for this may be the reintroduction of vocational school students into university quota. Still, the expansion of the Estonian higher education sector from (effectively) six institutions in 1987 to 34 in 2009/2010 (EMEaR 2010) exceeds the pace of growth of even Romania, which has the 'most widely discussed higher education explosion in the post state-socialist Eastern Europe' (Tomusk 2004:46). For a population of just 1.3 million, Estonia has probably the highest ratio of higher education institutions per inhabitant in Europe today giving rise to the clearly elevated levels of graduates compared to the other FSU and CEE countries in this study. Even more strikingly, after the dissolution of the Soviet Union, inside a time span of only six years in the 1990s, the share of female students and degree attainers increased dramatically (and males decreased) out of the student total (EMEaR 2010, EC 2009), as could be expected based on our results of cohort attainment levels. Heidmets et al. (2011) agree that the feminization of higher education is a prevalent trend in the Baltic states, and Estonia in particular. One of the stipulated reasons is that after the Soviet Union, humanities and social sciences became very popular especially among female students, and since there was no political control over these fields any longer, they attracted many new students to higher education. This view is supported by Ianelli and Smyth (2008) who conclude in a cross-European study that gender differences in educational and early labour market outcomes are derived from the field of study rather than the educational level attained. However, Estonia is considered to be one of the pioneers for female labour participation as well as the higher rate of females than males profiting from education (Titma et. al 2010). 


\section{Russia}

As with other affected socialist countries, Russia itself finds the legacy of the immense and inefficient Soviet education systems difficult to upgrade. Especially replacing the former fiscal control by the state has been a challenge yet to be overcome. At the same time, the collapse of the centrally planned economy and large public sector industries raised unemployment to high levels, further increasing social demand for higher education opportunities. Enrolment in higher education institutions started going down in the late 1970s due to economic problems (Tomusk 2004). While the number of students with secondary education increased quickly, the tertiary education was stratified in terms of equal opportunities and far from being able to adjust its capacity, often at the cost of disadvantaged classes (Gerber and Hout 1995, Micklewright 1999). The universities were fast running out of material and human resources in the decades following the 1980s. Tomusk (2004) highlights two points of failure of the Soviet higher education system, one being the lack of free intellectual enquiry and the other being the size of the higher education system in contrast to the low level of achievements produced for national development in both economic and industrial terms. On a greater scale, poverty still blocks Russia's access to information technology on certain scales and the language barrier further separates academics from large scale information sharing and internationalization.

\section{Poland}

The Polish case stands out due to a long history of prestigious higher education institutions that have repeatedly faced extinction and endured human loss. More recently, it is also a case of massification of higher education and the most extensive system of private institutions in Europe (Dobbins and Knill 2009).

Contrary to the other country examples, in Poland the link between education and research was upheld, and some contact with the Western science community was tolerated. This allowed the 'Humboldtian' tradition to be better preserved in Polish universities in general (Dobbins 2011, cf. Table 1). In 1990 a new Higher Education Act facilitated the switch from elite to mass higher education, allowing anyone the right to open a private higher education institution (Dobbins 2011). A drastic increase in enrolment rates ensued as commercial programs in largely private institutions gave promise of better career opportunities also to the less academically oriented. The combination of fiscal constraints in the public sector and fast expansion left the academic staff in a position to manoeuver between the public and private institutions for adequate personal sustenance. 


\section{Bulgaria}

Under communism, the Bulgarian system was largely closed and isolated, research and teaching being held separate and the Soviet curricula dominating the education (Dobbins 2011). As in most countries outlined here, the pre-war higher education legacy set the pace for the development after the Soviet era. In Bulgaria, the pre-war model was based on British influences more than in the other Central and Eastern European counterparts (cf. Table 1), however, there was only one pre-war university and a weak degree of institutionalization over the sector (Dobbins 2011). Thus, after 1989 the path towards university autonomy was a rather turbulent one for Bulgaria, depicting the tensions between state, academic interests and market forces. A course of fragmented expansion followed, individual faculties and units aiming for privatization in order to collect tuition fees, numbers of institution and students increased uncontrollably while a material and personnel basis was lacking. This is in line with the numerical findings of this study, namely the increases in both female and male attainment levels (see Fig. 4). Dobbins (2011:125) labels the Bulgarian situation as one of academic anarchy, without necessary measures guaranteeing academic quality nor strategic management capabilities. Perhaps it is in fact the lack of quality assurance that has kept the Bulgarian men from entering the local higher education in larger scale, being potentially more mobile than women, and thus able to pursue education outside the country borders. In the 21st century, in the wake of the Bologna Process, Bulgarian state has regained its role of system design and new Higher Education Laws were passed in 2002 and 2004 hopefully introducing functional guidelines and quality assurance for higher education institutions and their governance.

\section{Conclusions}

The existence of a strong pre-war education model seems to be a predictor of attainment outcomes for many of the countries that were under Soviet rule. The countries performing least favourably in terms of their attainment trends throughout the transition period seem to be the ones that had a 'Napoleonic', or nation state referential community co-ordinating their pre-war higher education sectors. Despite having in common low salaries, even payment arrears of teaching personnel and the academia, many of the 19 countries studied had, in the transition period, quickly diverted from the 'common' Soviet education trends towards individual paths. Only for the Asian FSUs, the Soviet system may have provided fertile ground for bribery and corruption in higher education (Temple and Petrov 2004), hampering the increase of higher education attainment levels up to this day.

Equally common are the still wide spread low state contributions to education and facilities, and the consequent heavy increase in privatization of the higher education sector, as well as increasing use of tuition as means of sustenance for the institutions. 
This is the case to a great extent in Estonia where the number of private institutions has soared, and in Poland where many academics work two jobs, one in the academe and another in the private college market. At the same time, this means for the students a more varied market for obtaining degrees, namely for those who are willing to pay their way through university.

The general global trend in education seems to be one of increasing proportions of the highly educated. Especially during the (again) challenging world economy, it comes as no surprise that ' $[\mathrm{t}] \mathrm{he}$ demand for higher education could be attributed, at least partially, to the larger proportion of young people opting for an extension of their studies in order to escape increasing youth unemployment and postpone their labour market entry' (Saar et al. 2008). While there is nothing wrong with pursuing higher education in hopes of bigger returns, it is desirable to exhibit sufficient overall control over the systems of education so as not to compromise the quality of the education. As seems to be the case with many of the countries studied here, education opportunities are taken on by the population faster and more eagerly than any control mechanisms that can be put in place.

Especially throughout transitional stages in institutional governance, particular care should be taken to ensure that the clients of the institutions (students, in this case), are not being exploited. The vast increases in education attainment levels (esp. female) after the Soviet breakup, seems to echo a public demand for high quality education for all. At the same time the institutional challenges must not be ignored by governments, in whose interest it is to provide a match between the educated population and the local labour market.

Further study areas could include the contemporary attainment level outcomes of the highly privatised higher education systems in many of the post-Soviet countries.

\section{Acknowledgements}

ET wishes to thank the Academy of Finland for funding in the years leading to this publication, and Hilal Erkus-Öztürk for helpful comments. 


\section{References}

Altbach, P.G., Reisberg, L. \& Rumbley, L.E. (2009). Trends in Global Higher Education: Tracking an Academic Revolution. Paris: UNESCO.

Barro, R.J. \& Lee, J.W. (2010). A New Data Set of Educational Attainment in the World, 1950-2010. NBER Working Paper No. 15902.

Barro, R.J. \& Lee, J.-W. (2000). International Data on Educational Attainment Updates and Implications. NBER Working Paper No. 7911.

Benavot, A. (1989). Education, Gender, and Economic Development: A Cross-National Study. Sociology of Education 62 (1), 14-32.

Brunner, J.J. \& Tillett, A. (2007). Higher education in Central Asia: The challenges of modernization: Case studies from Kazakhstan, Tajikistan, The Kyrgyz Republic and Uzbekistan. Washington, DC: World Bank.

Charles, M. (2005). National Skill Regimes, Postindustrialism, and Sex Segregation. Social Politics: International Studies in Gender, State and Society 12, 289-316.

Charles, M. \& Bradley, K. (2002). Equal but separate? A cross-national study of sex segregation in higher education. American Sociological Review 67, 573-99.

Crespo Cuaresma, J. \& Lutz, W. (2007). Human Capital, Age Structure and Economic Growth: Evidence from a New Dataset. IIASA Interim Report IR-07-011. Laxenburg.

David-Fox, M. \& Péteri, G. (2000). On the origins and demise of the communist academic regime. In M. David-Fox and G. Péteri (Eds.) Academia in upheaval: Origins, transfers, and transformations of the communist academic regime in Russia and east central Europe, pp. 3-35. Westport, Conn.: Bergin \& Garvey.

Dobbins, M. (2011). Higher Education Policies in Central and Eastern EuropeConvergence towards a Common Model? Basingstoke: Palgrave Macmillan.

Dobbins, M. \& Knill, C. (2009). Higher Education Policies in Central and Eastern Europe: Convergence toward a Common Model? Governance: An International Journal of Policy, Administration, and Institutions 22(3), 397-430.

European Commission (2009). Key data on education in Europe 2009. Brussels: Education, Audiovisual and Culture Executive Agency.

Estonian Ministry of Education and Research (2010). Statistiline ülevaade kõrghariduse õppekavadel õppijate näitajatest [Statistical overview of the indicators in higher education]. Tartu: Haridus- ja Teadusministeerium.

Ganzeboom, H.B.G. \& Nieuwbeeerta, P. (1999). Access to education in six Eastern European countries between 1940 and 1985. Results of a cross-national survey. Communist and Post-Communist Studies 32, 339-57.

Gerber, T.P. \& Hout, M. (1995). Educational Stratification in Russia During the Soviet Period. American Journal of Sociology 101(3), 611-60.

Gerber, T.P. \& Schaefer, D.R. (2004) Horizontal Stratification of Higher Education in Russia: Trends, Gender Differences, and Labor Market Outcomes. Sociology of Education 77(1), 32-59.

Heidmets, M., Kangro, A., Ruus, V., Matulionis, A.V., Loogma, K. \& Zilinskaite, V. (2011). Haridus [Education]. In Eesti Inimarengu Aruanne 2010/2011. Inimarengu Balti rajad: muutuste kaks aastakümmet [Estonian Human Development Report 2010/2011. The Baltic paths of human development: Two decades of changes], ed. Marju Lauristin, 96-115. Tallinn: Eesti Koostöö Kogu. 
Heyneman, S.P., Anderson, K.H. \& Nuraliyeva, N. (2008). The Cost of Corruption in Higher Education. Comparative Education Review 52, 1-25.

Heyneman, S.P. (2007). Three universities in Georgia, Kazakhstan and Kyrgyzstan: the struggle against corruption and for social cohesion. Prospects 37, 305-18.

Hüfner, K., ed. (1995). Higher Education Reform Processes in Central and Eastern Europe. Frankfurt am Main: Peter Lang.

Ianelli, C. \& Smyth, E. (2008). Mapping gender and social background differences in education and youth transitions across Europe. Journal of Youth Studies 11(2), 213-32.

Jacobs, J.A. (1996). Gender Inequality and Higher Education. Annu. Rev. Sociol. 22, 153-85.

Johnson, M.S. (2008). Historical legacies of Soviet higher education and the transformation of higher education systems in post-Soviet Russia and Eurasia. In D.P. Baker and A.W. Wiseman (Eds.) The Worldwide Transformation of Higher Education and Society, vol. 9, pp. 159-76. Emerald Group Publishing Limited.

Jolliffe, D. \& Campos, N.F. (2005). Does market liberalisation reduce gender discrimination? Econometric evidence from Hungary, 1986-1998. Labour Economics 12, 1-22.

Kostera, M., Proppe, M. \& Szatkowski, M. (1994). Beyond the social role: the case of Polich female professionals. Scandinavian Journal of Mangement 10(2), 99-116.

Kotásek, J. (1993). Visions of educational development in the post-socialist era. International Review of Education 39(6), 473-87.

Lee, R. D. (1985). Inverse projection and back projection: A critical appraisal, and comparative results for England, 1539 to 1871. Population Studies 39, 233-48.

Lobodzinska, B. (2000). Polish Women's Gender-Segregated Education and Employment. Women's Studies International Forum 23, 49-71.

Lutz, W., Goujon, A., K.C., S. \& Sanderson, W. (2007). Reconstruction of population by age, sex and level of educational attainment of 120 countries for 1970-2000. Vienna Yearbook of Population Research, vol. 2007, 193-235.

Mateju, P., Rehakova, B. \& Simonova, N. (2004). Cultural and socio-economic origins of unequal opportunities in attaining higher education in the Czech Republic (1948-1999). Sociologia 36(1), 31-56.

Micklewright, J. (1999). Education, inequality, and transition. Economics of Transition 7(2), 343-376.

Munich, D., Svejnar, J. \& Terrell, K. (2005). Returns to Human Capital under the Communist Wage Grid and during the Transition to a Market Economy. The Review of Economics and Statistics, 87(1), 100-123.

Newell, A. \& Reilly, B. (1999). Rates of Return to Educational Qualifications in the Transitional Economies. Education Economics 7, 67-84.

OECD (2006). Education at a Glance: OECD Indicators 2006. Paris: OECD.

OECD (2007). OECD Reviews of Tertiary Education: Estonia. Paris: OECD.

OECD (2008). Trends Shaping Education. Centre for Educational Research and Innovation (CERI), Paris: OECD.

Paci, P. (2002). Gender in Transition. Washington, D.C.: World Bank. 
Pascall, G. \& Lewis, J. (2004). Emerging Gender Regimes and Policies for Gender Equality in a Wider Europe. Journal of Social Policy 33(3), 373-94.

Paternostro, S. \& Sahn, D.E. (1999). Wage Determination and Gender Discrimination in a Transition Economy: The Case of Romania. World Bank Policy Research Working Paper No. 2113.

Saar, E. (1997). Transitions to Tertiary Education in Belarus and the Baltic Countries. European Sociological Review 13(2), 139-58.

Saar, E., Unt, M. \& Kogan, I. (2008). Transition from Educational System to Labour Market in the European Union: A Comparison between New and Old Members. International Journal of Comparative Sociology 49(1), 31-59.

Silova, I. \& Magno, C. (2004). Gender equity unmasked: democracy, gender, and education in Central/Southeastern Europe and the Former Soviet Union. Comparative Education Review 48(4), 417-42.

Simkus, A. \& Andorka, R. (1982). Inequalities in educational attainment in Hungary, 1923-1973. American Sociological Review 47(6), 740-51.

Smyth, E. \& Steinmetz, S. (2008). Field of Study and Gender Segregation in European Labour Markets. International Journal of Comparative Sociology 49, 257-81.

Stanovnik, T. (1997). The Returns to Education in Slovenia. Economics of Education Review 16, 443-49.

Szebenyi, P. (1992). Change in the systems of public education in the East Central Europe. Comparative Education 28(1), 19-31.

Temple, P. \& Petrov, G. (2004). Corruption in Higher Education: Some Findings from the States of Former Soviet Union. Higher Education Management and Policy 16(1), 83-99.

Titma, M., Roots, A. \& Soidla, I. (2010). Gender Differences in Intragenerational Mobility: The Case of Estonia. European Sociological Review 26(3), 337-50.

Titma, M. \& Saar, E. (1995). Regional differences in Soviet secondary education. European Sociological Review 11(1), 37-58.

Titma, M., Tuma, N.B. \& Roosma, K. (2003). Education as a factor in intergenerational mobility in the Soviet society. European Sociological Review 19(3), 281-97.

Tominc, P. (2002). Some aspects of the gender wage gap in Slovenia. Drustvena istrazivanja 11(6), 879-96.

Tomusk, V. (2004). The open world and closed societies: essays on higher education policies 'in transition'. New York: Palgrave Macmillan.

UNESCO (1997). International Standard Classification of Education I S C E D 1997. Paris: UNESCO.

Wrigley, E.A. \& Schofield, R.S.(1982). The population history of England, 1541-1871: A reconstruction. Cambridge, MA: Harvard University Press.

Yodanis, C.L. (2004). Gender Inequality, Violence Against Women, and Fear: A Cross-National Test of the Feminist Theory of Violence Against Women. Journal of Interpersonal Violence 19, 655-75. 